\title{
Romanın Sinemaya Aktarımında Karşılaşılan Problemlere Kuramsal Yaklaşımlar*
}

\section{Orhan Güdek ${ }^{* *}$}

\begin{abstract}
O̊z
Bu çalışmanın amacı, yazılı ve görsel anlatılar arasındaki ilişkiyi inceleyerek, özelde romandan sinemaya aktarım sürecinde ortaya çıkan problemlere kuramsal bir yaklaşımla çözüm önerileri getirmektir. Bize göre bu sorunların kaynağının başında görüntünün doğasına ait bir kavram olan, "gerçeklik yanılsaması" gelmektedir. Çalışmada, bir romanın sinemaya aktarımındaki problemlerin aslında romanla sinema arasındaki ilişki biçiminden değil, görüntü ve gerçeklik arasındaki ilişki biçiminin doğru kurulamamasından kaynaklandığı savunulmuştur. Görüntüye, bir gösterge olduğundan hareketle gerçekliğin arkasındaki farklı anlam katmanlarını iletmeye çalışan ve ona, gerçekliğin bir göstergesi olarak yaklaşan düşünce biçiminin, romandaki soyut kavram ve durumların aktarılabilmesinin önünü açacağı ve yönetmene geniş bir hareket imkânı tanıyacağı gerçeğine ulaşılmıştır. Ayrıca "romana sadakat" sorunları çerçevesinde de konu ele alınarak yönetmenin romana olan mesafesi üzerinden kuramsal sorgulamalar yapılmıştır. Edebi bir romanı kaynak alan filmlerin, sinemanın sanatsal olan tarafında durması gerektiği ve bir filmin romandan alması gereken en önemli özelliğin "edebilik" olduğu iddia edilmiştir.
\end{abstract}

\section{Anahtar Kelimeler}

Roman, sinema, yazılı anlatı, görsel anlatı, uyarlama, gerçeklik yanılsaması, kuram.

\footnotetext{
Geliş Tarihi: 15 Ocak 2016 - Kabul Tarihi: 21 Aralık 2016

Bu makaleyi şu şekilde kaynak gösterebilirsiniz:

Güdek, Orhan (2019). Romanın Sinemaya Aktarımında Karşılaşılan Problemlere Kuramsal Yaklaşımlar. bilig - Türk Dünyası Sosyal Bilimler Dergisi 90: 117-135.

** Doktorant, Sakarya Üniversitesi, Sosyal Bilimler Enstitüsü, Türk Dili ve Edebiyatı Anabilim Dalı, Türk Dili ve Edebiyatı Bölümü - Sakarya/Türkiye

ORCID ID: https://orcid.org/0000-0001-9928-1612

orhangultenzey@gmail.com
} 


\section{Giriş}

Sinemanın tarihi on dokuzuncu yüzyılın sonundan başlatılmasına karşın insanoğlunun gördüğü şeyleri resimleme ve resimlediklerini hareket ettirme arzusu ve hayali tarih öncesi çağlara değin uzanır. Avrupảnın değişik yerlerinde bulunan paleolotik çağa ait mağaralardaki resimlerde at, bizon ya da yaban keçisi gibi hayvanların birçoğunun hareket halinde betimlenmiş olması, insanoğlunun bu hayalinin günümüze uzanan örnekleridir.

Fakat resmin gerek en eski gerekse de en yeni örnekleri, hareketi değil ancak hareketin bir an'ını tespitten öteye geçememiştir. Bununla birlikte insanoğlunun, resimleri hareket ettirebilen bir aygıt için, on dokuzuncu yüzyılın sonlarını beklemesi gerekmiştir. Lui ve August Lumier Kardeşler' in 28 Aralık 1895 'te Paris Grand Cafe'de halka açı yaptıkları ilk film gösterimi, sinemanın başlangıcı sayılır. Ancak "sinematograf" adı verilen ve resimlerin arka arkaya gösterilerek hareketliymiş algısını uyandıran buluşa giden yolda birçok bilim adamının da payı vardır. ${ }^{1}$

İlk sinema gösterimleri bir öykü anlatmaktan çok belgesel niteliği taşımaktaydı. Ancak içinde az da olsa bir öykü barındıran film parçalarının daha çok ilgi gördüğünün keşfedilmesi, sinemayı ilk zamanlarından itibaren edebîyat eserlerine yönlendirmiştir. Jules Verne, Victor Hugo, Alexandre Dumas, Dickens gibi yazarların birçok eseri, sinemanın öncüsü sayılan yönetmenler tarafından filme çekilmiştir. Hazır, denenmiş ve okurca beğenilmiş olan edebîyat eserlerinin filmlerinin yapılması, yazılı metinlerin sinemaya nasıl aktarılacağı sorununu da beraberinde getirmiş, bu ise sinemanın anlatım imkânlarının gelişmesi ve genişlemesini sağlayarak "yeni bir dil" inşa edilmesinde büyük katkı sağlamıştır.

Günümüzde sinema, dünya genelinde ortak bir anlatım dili oluşturmuş olmasına karşın, ilk yıllarında olduğu gibi edebîyat eserlerine, özellikle de roman'a başvurmaya devam etmektedir. Ancak yazılı ve görsel anlatı ile bu anlatıların dilleri arasındaki farklılıklar edebîyat eserlerinin sinemaya aktarılmasında bir takım problemleri de beraberinde getirmektedir. Sinemanın kendine özgü bir anlatım dili oluşturmasına, bu dili kullanarak bir öyküyü nasıl anlatacağına dair birikimine ve sahip olduğu ileri teknolojiye rağmen, edebîyatın dinamik ve değişken yapısı, görsel dile aktarımındaki sorunların güncel kalmasına sebep olmuştur.

Bu makalede, yazılı ve görsel dil arasındaki benzerlik ve farklılıklar üzerin- 
de durularak, sinemaya en çok aktarılan edebî tür olması sebebiyle özelde roman türünün görsel dile aktarımında karşılaşılan problemlere değinilmiş, uyarlama (adaptation) ve dönüştürüm (converting) açllarından bu problemlere çözüm önerileri getirilmeye çalışılmıştır.

Şüphesiz ki romanın ve filmin anlatım dili farklıdır. Bu farklılıktan hareketle bir romanın görsel dile aktarım sürecinde öncelikle romanın incelenerek, yapısının ve içeriğinin ortaya konması gerekmektedir. Ancak bize göre sorunların kaynağının başında görüntünün doğasına ait bir kavram olan, "gerçeklik yanılsaması" gelmektedir. Bu çalışmada, bir romanın sinemaya aktarımındaki problemlerin aslında romanla sinema arasındaki ilişki biçiminden değil, görüntü ve gerçeklik arasındaki ilişki biçiminin doğru kurulamamasından kaynaklandığı savunulmuştur. Ayrıca "sadakat" sorunları çerçevesinde de konu ele alınarak yönetmenin romana olan mesafesi üzerinden kuramsal sorgulamalar yapılmıştır. İddiamız odur ki, edebî bir romanı kaynak alan filmlerin, sinemanın sanatsal olan tarafında durması gerektiği ve bir filmin romandan alması gereken en önemli unsurun, romanın "edebîlik" özelliği olduğudur.

Konuyla ilgili yurtdışında birçok çalışma yapılmasına karşın ülkemizde yapılan akademik çalışmalar ve tartışmalar henüz yeterli düzeyde değildir. Romandan sinemaya yapılan uyarlamalarla ilgili yapılmış olan çalışmaların çoğu romanın ve filmin ayrı ayrı incelenmesi ya da filmin romana sadık kalıp kalmadığı tartışmalarının etrafında dönmektedir. Çalışmaların bir kısmının da birbirini tekrar eden ansiklopedik bilgilerle sınırlı olduğu görülmektedir. Teorik anlamda yazılı ve görsel dilin mukayesesi esasına dayanan ve uyarlama süreçlerini inceleyen yetkin kuramsal çalışmaların eksikliği hala hissedilmektedir. Çalışmamızın amacı, yazılı ve görsel anlatılar arasındaki ilişkiyi inceleyerek, özelde romandan sinemaya aktarım sürecinde ortaya çıkan sorunlara ve mevcut kuramsal tartışmalara katkıda bulunmaktır.

\section{Gerçeklik Yanılsaması, Sözcükler ve Görüntünün Doğası}

Gönül gözü görmeyince hiç baş gözü görmeyiser.

Yunus Emre

Yazılı ve görsel anlatıların dilleri birbirinden farklıdır. Birçok kaynakta anlatının temelini oluşturan şeyin, yazılı anlatılarda "sözcükler", görsel anlatılarda ise "görüntü" olduğu ifade edilir. Elbette bir roman, dili oluşturan sözcüklerle kurulurken; bir film, görüntü parçalarının bir araya gelmesiyle 
oluşur. Ancak roman ve sinema arasında, kullandıkları malzeme itibariyle temelde farklılık olsa da her ikisinin de amacı, bu farklı malzemeyi kullanarak, bir öykü anlatmaktır. Fakat "anlatı ortamının doğası", aynı öykünün farklı biçimlerde ifade edilmesine sebep olmaktadır. Bir öykünün, bir roman ya da bir filmde nasıl anlatıldığının ya da söz konusu anlatı ortamlarında "anlam"ın nasıl sağlandığı ya da değiştiğinin analizi, öncelikle her iki ortamın dilini oluşturan temel birimlerin ve bu birimler arasındaki ilişkinin incelenmesine bağlıdır. Birimler üzerine ontolojik bir düşünme biçimi, aktarım sürecinde nasıl bir pozisyon alınması gerektiğine dair bir fikir verecektir.

Bir romanı oluşturan en küçük anlamlı birim sözcüklerdir. Göstergebilim kuramlarına göre sözcükler, kendi dışındaki "şey"lere işaret eden göstergelerdir. Örneğin, toplumsal uzlaşım gereği "yağmur" sözcüğünü oluşturan işaretlerin bir araya gelmesi, herkesin bildiği bir doğa olayına işaret eder. "Yağmur" sözcüğünü gören birinin zihninde, sözcügüun işaret ettiği nesnenin hayalî görüntüsü ve bu görüntünün farklı anlamsal çağrışımları belirir. Bir filmin yapıtaşı ve en küçük anlamlı birimi olan fotoğrafik görüntüler için de aynı şey geçerlidir. Yazıdaki "yağmur" sözcüğü ile görüntüdeki "yağmur" görseli, kendi dışındaki başka bir şeye işaret etmeleri bakımından aynıdır. Gördüğümüz şey aslında yağmurun kendisi değil "yağmur" yazısı ya da "görüntüsüdür".

Bir filmde görülen yağmur, tıpkı "yağmur" sözcüğünün işaret ettiği gibi, önce, görüntünün nesnesine göndermede bulunur. Fakat yazı dilinde "gösteren" ile işaret ettiği nesne arasında görüntü itibariyle hemen algılanabilen ayrım, görsel dilde, "gösteren"in, nesnesiyle olan "aynı gibilik" ilişkisi yüzünden kolayca idrak edilemez. Bu durum görsel anlatılarda devinim’in devreye girmesiyle daha şiddetli bir hale gelir ve görülenin gerçek olduğu yanılsaması had safhaya ulaşır. Böylece gösteren ile gösterilen birbirinden ayırt edilemez bir hal alır.

Sinema tarihi kaynakları, ilk film gösteriminin yapıldığ 1 Paris Grand Cafe'de, seyircilerin "Trenin Gara Girişi" filmini izlerken üstlerine doğru gelen trenden korkup panik halinde kaçıştıklarını yazar. Devinimli görüntüye şahit olan ilk sinema izleyicilerinin bu davranışları, gösterge ile göstergenin nesnesinin ayırt edilememesinden kaynaklanmıştır. Gombrich'e göre imge ile gerçeklik arasındaki ayrım, ilkeller için bazen çok daha belirsizdir. "Yerliler, bir keresinde, sürülerinin resmini yapan Avrupalı bir ressama, korkuyla 
şu soruyu sormuşlardır: Bunları alıp götürürsen neyle yaşarız biz? (1997: 40). Bugün sinema izleyicisi bir filmdeki devinimli görüntülerin "gerçek" olmadığının bilincindedir; ancak film izleme deneyimi sırasında bu bilinç, gerçeği temsil eden kopya görüntünün gerçek olduğu yanılsamasından dolayı, özdeşleşmenin de etkisiyle zaman zaman kaybolabilir.

Her sanat türü az ya da çok seyircinin gerçeklik duygusuna seslenir; en çok da sinema. (...). Beyazperdede geçen olay ne kadar gerçek dışı olursa olsun, seyirci buna tanık olur ve deyim yerindeyse olaya katılır. Bu nedenle, olayların gerçek olmadığını bilmesine karşın sanki gerçekmiş gibi duygusal bir biçimde tepki gösterir (Lotman 1999: 26).

Bir filmi oluşturan görüntüler durağan fotoğraf kareleridir. Barthes’a göre (2014: 18), bir fotoğrafı, göndergesinden ayırt edebîlmek ayrı bir bilgi ve bilinç durumunu gerektirir. Nesne, taklit edilme biçimi tarafından engellenmiş olduğu için, göze nasıl görünürse görünsün, ne türden olursa olsun, fotoğraf görünmez, gördügümüz şey aslında o değildir. Kısaca gönderge ayrılmaz ve bu eşine az rastlanır bağlılık fotoğraf üzerinde yoğunlaşmayı çok zorlaştırır. Ona göre, "fotoğrafik gösteren"in görülebilmesi için fotoğrafa "çok yakından bakmak" gereklidir.

Görüntünün gerçekliğiyle ilgili sözü edilen yanılsama, bir romanın görüntü diline aktarılması sürecinde ortaya çıkan problemlerin ilk kaynağını teşkil eder. Çünkü "gerçeklik yanılsaması" romandaki soyut kavram ve durumların görüntü diline aktarılmasının önündeki en büyük engeldir. Oysa görüntü de tıpkı romandaki sözcükler gibi, gerçeğin kendisi değil bir göstergesidir. Uygun tasarım ve sıralama yapıldığı takdirde romandaki soyut kavramlar ve durumların görüntü diline dönüştürümü (converting) kolaylaşacaktır. Dolayısıyla yazı diliyle ifade edilen romanın, görüntü diline dönüştürülmesinde, "gerçeklik yanılsaması"ndan bağımsız düşünerek, fotoğrafik görüntüye öncelikle bir "yazı türüymüş" gibi yaklaşmak gerekmektedir.

$\mathrm{Bu}$ türden bir düşünme biçimiyle sinemaya yaklaşan ve sinema dilinin oluşmasında büyük katkıları olan Eisenstein, Japon geleneksel yazısı "haiku"yu, sinemadaki kurgunun ilk adımı olarak görür.

Bu hiyerogliflerden ${ }^{2}$ her biri ayrı bir nesne'ye bir olguya karşılıktır; ama birleşmeleri bir kavram'a karşılık olur. Kaynaşmış ayrı ayrı hiyerogliflerden de kavramsal yazı oluşur. 'Gösterilebilir' iki hiyeroglifin birleşmesiyle, çizgiyle 
'gösterilemeyecek' bir şeyin anlatımı sağlanmıştır. Örneğin, suyun resmi ile gözün resmi 'ağlamak' anlamına gelir; bir kapı resminin yanında bulunan bir kulak resmi 'dinlemek' demektir (.). İyi ama bu kurgudur. Evet, bu tıpatıp bizim sinemada yaptığımız şeydir. Resmi yapılabilir, anlamı tek, içeriği yansız (nötr) olan çekimleri, anlıksal (intellectual) birlikler ve diziler biçimine sokmak. Herhangi bir sinemalık sergilemede kaçınılmaz bir araç ve yöntemdir bu. Yoğunlaşmış ve arılaşmış bir biçimde de 'anlıksal sinema'nın çıkış noktası. Soyut kavramların görsel anlatımında en aşırı özlülüğü (laconism) arayan bir sinemanın (Eisenstein 1985: 44).

Kurgu, dildeki sözdizimine benzer. ${ }^{3}$ Tek tek görüntülerin ne şekilde sıralandığı iletilmek istenen anlam üzerinde belirleyici bir rol oynar. Örneğin birinci görüntüde bıçak tutan bir el, ikinci görüntüde ağaca bağlanmış bir koyun görülürse, zihin bu görüntülerden bir çıkarım yapar ve koyunun kesileceği sonucuna varır. Ancak üçüncü görüntüde bıçağı tutan elin gülümseyen küçük bir çocuğa ait olduğu görüldüğünde, zihin yeni bir çıarım yaparak çocuğun koyunun ipini keserek onu kurtaracağını düşünür. ${ }^{4}$ İnsanoğlunun ilk yazma biçiminin resimsel yazı olduğu hatırda tutularak, gerek tek tek görüntülerin nesnelerinden öte bir anlam ifade etmesi, gerekse de bu görüntülerin diziliminin yeni anlamlara yol açması, görüntünün bir yazı biçimi olduğu gerçeğini destekler niteliktedir.

Leaman, dünyayı, arkasında açıklamaların yattığı bir yer olarak gören ve realiteyi, yorumlama gerektiren bir biçimde temsil eden tarzın, izleyicinin gördüğü şeyin yorumunun önemini vurgulayan tasavvufi estetik tarz olduğunu belirtir (2012: 240). Bu itibarla, görülenin, gerçeğin kendisi olduğunu dayatan bir sinema anlayışı yerine; gerçeğin, görülenin kendisi olmadığını hatırlatan bir sinema anlayışı, gerçeklik yanılsamasından kaynaklı görsel anlatı sorunlarının çözümü noktasında tasavvufi bir bakış açısıyla birlikte yönetmene sınırsız açılımlar sağlayacaktır. Romandan sinemaya aktarımlarda yalnızca görülebilir olanı değil görülemeyeni de "görebilmek" ve görüntü diline aktarabilmek böyle bir bakış açısının sonucudur. Örneğin, görüntüde ihtiyar bir adam gösterilmek isteniyorsa dünyanın her yerinde ihtiyar bir adam gösterilir. Fakat Abbas Kiyarüstemi'nin "Arkadaşımın Evi Nerede?"5 filmindeki ihtiyar adam, genel yapı ve kurgu içinde, yalnızca bir ihtiyar adam değil, aynı zamanda "gelenektir" de. Ya da aynı yönetmenin "Koro"6 adlı kısa filminde ancak işitme cihazıyla duyabilen ihtiyar, "devlet"tir as- 
lında. İyi filmler bu türden ifade biçimlerinin sayısız örnekleriyle doludur.

Görüntüye bir yazı türü olduğu biçimindeki yaklaşımda, görüntülerin filmin genel yapısı içinde nasıl konumlandırıldığının yanı sıra, sinema sanatına özgü diğer teknikler ve filmin üretildiği "kültürel coğrafya"nın etkisi gibi unsurlar da, romanın filme aktarılması sürecinde göz ardı edilmemelidir. Sanatsal ürünün ait olduğu ya da yeniden üretildiği kültür alanı, görüntüsel yazının nasıl okunacağı noktasında belirleyici olacaktır. Bir İran filminde bereket ve rahmetin simgesi olarak yer alan "yağmur"un, bir Amerikan filminde korku, gerilim ve kötü şeyler olacağının habercisi olarak kullanılması, gerçeğin algılanışı, anlamlandırılması ve anlamın iletilmesindeki kültürel farklılıklara bir örnektir.

Eğer görüntü bir "yazı" biçimiyse, görüntülerden oluşan filmin de bir "metin" olduğu düşünülmelidir. Bir dilde yazılan bir metnin başka bir dile çevrilme sürecinde sözcükler ya da cümlelerin birebir çevirisi nasıl yapılamıyorsa, bir romanın da farklı bir dil olan sinema metnine doğrudan ya da birebir aktarımı söz konusu olamaz.

\section{Bir Hareket Noktası Olarak Roman}

Uyarlama ciddi bir sorundur edebîyat sinema ilişkisinde. Sinemacı, şüphe yok ki, bir kitabı seçti diye onun kulu kölesi olacak değildir. Ama kaynaktaki temellendirme budanirsa, yerine bir yenisini koymak gerekir ${ }^{7}$

Enis Batur

Romandan filme yapılmış aktarımlarda genellikle "esere sadakat" kavramından hareketle bir tartışma yürütülür ve ortaya çıkan filmin başarı ya da başarısızlı̆ı̆, roman ile film arasında bir kıyaslama yapılarak, filmin kaynak eser olan romana ne kadar bağlı olup olmadığıyla ölçülür. Geçmişte roman yazarlarının da katıldığı bu türden tartışmaların bugün son derece absürd olduğu aşikârdır.

Bir film romana uzamsal olarak çok yakın ya da çok uzak bir noktada durabilir. En yakın noktada "dönüştürüm"den (converting), en uzak noktada ise romanın yalnızca bir hareket noktası olarak kabul edildiği "esinlenme"den söz edilebilir. Her iki nokta arasındaki gidiş gelişleri kapsayan süreç ise "uyarlama" (adaptation) kavramıyla karşılanabilir. Romanın sinemaya 
aktarım çalışmalarında yöntemi belirleyen husus ise, birbirinden ayrı bu iki nokta arasındaki gidiş gelişlerle alakalıdır. Eğer yönetmen sinema estetiği çerçevesinde romandaki unsurların birçoğunu atlamadan filme aktarmak istiyorsa, "dönüştürüm" noktasına daha yakın duruyor demektir. Dolayısıyla yönetmenin karşılaşacağı problemler "esinlenme" noktasında olduğundan çok daha farklı olacak ve romanın teknik dünyasına daha fazla girmesi gerekecektir.

Uyarlamaların yönü, teorik olarak, herhangi bir sanat dalından bir başka sanat dalına doğru olabileceği gibi, aynı sanat dalı içerisindeki türler arasında da gerçekleşebilir. ${ }^{8}$ Romandan sinemaya yapılan uyarlamalarda yönetmen hangi noktada durursa dursun, yazarın hukuki hakları dışında, onun için bağlayıcı herhangi bir konu bulunmamalıdır. Yönetmen, temel aldığı romanın bütün unsurlarını değiştirme, dönüştürme ve aklındakini perdeye yansıtma noktasında özgürdür. Nihayetinde ortaya çıkacak olan film, yeni bir sanat eseri yeni bir üretim ve bir başka sanatçı/üretici olan yönetmenin eseri olacaktır. ${ }^{9}$ Karşılaşılacak problemleri belirleyecek olan şey öncelikle, "klasik" ya da "modern" anlatı biçimine sahip romanların filme aktarımında söylem kaynaklı zorluk ya da kolaylıklardan ziyade, yönetmenin kaynak eser olarak gördüğü romana olan mesafesidir. Bu itibarla romanı birebir filme aktarmak çabası içinde olan yönetmenler olabileceği gibi romanı yalnızca bir hareket noktası olarak gören yönetmenler de olabilecektir.

Bazin'e göre (2011: 130), Raymond Radiguet'nin İçimizdeki Şeytan ${ }^{10}$ ve Andre Gide'in Pastoral Senfoni ${ }^{11}$ romanları belli aktarım kuralları ışığında filme uyarlanmış ve oldukça başarılı olmuşlardır. Çok sayıda film eleştirmeni bu filmlerin en az örnek aldıkları kitaplar kadar iyi olduklarını düşünürler. Ancak Bazin, aktarım formüllerinin dışına çıkarak oluşturulan serbest uyarlamalardan da söz eder:

Renoir'in gerçekleştirdiği 'Une Partie de Campagne'12 ve 'Madame Bovary'13 filmlerini buna örnek olarak verebiliriz. Burada sorun başka bir yolla çözülmüştür. Özgün metin sadece hayat bulma kaynağ1dır. Film yapımcısı ile romancı arasındaki bağlılık derin bir sempatik anlama dayanmaktadır. Film, bu tür uygulamada kitabın yedeği olma amacının ötesine geçerek, onun yerini alma gayesi gütmektedir. Bunun başarılı bir örneği olarak Renoir'in 'The River' (Nehir) filmini gösterebiliriz. 'Le Journal d'un cure de campagne' ${ }^{14}$ filmi bir 
kez daha farklılık göstermektedir. Onun diyalektiği, sadakat ile yaratım arasında gidip gelmektedir. Burada, edebîyat eserini, sinema ürününe dönüştürme işlevi bir sorun olarak karşımıza çıkmamaktadır. Roman baz alınarak, ikincil derecede bir çalışma oluşturulmaya çalışılır. Film, yeni bir estetik yaratım olmuştur artık. Filmin roman ile karşılaştırılmasına gerek yoktur (Bazin 2011: 130).

Gerek filmin başarısı gerekse de filmin romanın gölgesinde kalmaması için romanın yalnızca bir çıkış noktası ve bir itici güç gibi algılanması yerinde bir yaklaşım olacaktır. Romanın ne kadarının ve nasıl kullanılacağı yönetmenin tasarrufuna bağlı olmalıdır. Romanından kötü bir film çıktı diye kimse yazarı suçlamayacaktır. Filmin tüm sorumluluğu yönetmene aittir.

Enis Batur, yola çıktığı kitabı geniş ölçüde kullanan, ama ona sadık kalma niyeti hiç beslemeyen Hitchock, Antonioni, Truffaut gibi yönetmenlerin, tartışmasız bir biçimde başarıları oldukları tespitinde haklıdır. Batur’a göre üst anlatı (roman), genellikle sıradan, basit bir bahane oluşturur ve yönetmen kendi anlatmak istediklerini alttan alta filmin yerlemlerine ustalıkla dağıtır (1995: 296).

Romanın bir hareket noktası olarak görülmesi gerektiği yaklaşımının en başarılı örneklerinden biri, Boris ve Arkady Strugatsky kardeşlerin "Yol Kenarında Piknik" adlı romanından uyarlanan Tarkovski'nin kült filmi "Stalker"15dır. Tarkovsky, kendisiyle yapılan bir görüşmede romanın filmle olan bağlantısının yalnızca bir çıkış noktası olmasından öteye gitmediğini anlatır:

Dostum, yönetmen Giorgi Kalatozişvili'ye filmi uyarlayabileceği düşüncesiyle 'Yol Kenarında Piknik' adında kısa bir roman önermiştim. Sonra neden bilmiyorum, Giorgi romanın haklarını yazarlardan, Strugatski kardeşlerden alamadı ve filmi yapmaktan vazgeçti. Benim de böyle bir film yapma fikri kafamda dönüp durmaya başladı, başlarda zaman zaman aklıma düşüyordu, sonra giderek sıklaştı. $\mathrm{Bu}$ romanı temel alan bir yer, zaman ve eylem birliğiyle bir film yapılabilirmiş gibi geliyordu bana. (...) Stalker'ın senaryosunun 'Yol Kenarında Piknik' romanıyla, iki kelime, 'İz Sürücü’ ve 'Bölge' dışında hiçbir ortak noktası bulunmadığını da söylemem gerek (Tarkovski 2009: 62-63). 
Yönetmenin romana mesafesi ne olursa olsun, bir romandan hareketle yapılan filmlerin, romanı birebir yansıtma gibi bir zorunluluğu olmamalıdır. Çünkü film her ne kadar "romanı" temel alsa da romandan bağımsız ve yeni bir eserdir. Sinema tarihi esinlendiği anlatıyı birebir yansıtmaya çalışan filmlerin, hem sanatsal açıdan hem de gişede fiyaskoyla sonuçlandığı birçok örnekle doludur.

\section{Bir Okur Olarak Yönetmen}

Ne kadar bilirsen bil, söylediklerin karşındakinin anladiğı kadardır.

Mevlânâ Celâleddin Rûmî

Hem söylem hem içerik bakımından birbirinden farklı sayısız roman vardır. Bunların her biri için ayrı ayrı birer uyarlama yöntemi geliştirmek elbette mümkün değildir. Romanların tümünü kapsayabilecek tek bir uyarlama yönteminden de söz etmek imkânsızdır. Fakat bir romanın filme aktarılmasıyla ilgili belli ilkeler tespit edilebilir. Bunların başında, yönetmenin, kendi sanatının estetik kuralları içerisinde kalması şartıyla, romanın nesini, ne kadarını ve bunu nasıl yansıtacağının tercihi noktasında serbest olduğu ilkesi gelmelidir.

Söz konusu ilke, yönetmenin de sayısız roman okurundan herhangi bir okur olduğu gerçeğine dayanır. Yönetmeni sayısız roman okurundan bir okur olarak görmek, romandan sinemaya yapılan aktarımlar sonrasında filmin romanla kıyaslanması eğiliminden doğacak problemlerin önüne geçecektir. Çünkü burada önemli olan ve bilinmesi gereken nokta, "romanın" değil, bir okur olarak "yönetmenin roman algısının" filme yansıdığıdır. Yönetmenin roman algısında ise yazar, roman ve yönetmenin kendisini de içine alacak şekilde, zaman ve uzamla ilintili olan kültürel boyut belirleyici rol oynar.

Her şeyden önce yönetmen bir roman okurudur ve metnin iletildiği son nokta odur. Berna Moran, okuru önceleyen edebîyat eleştirisi kuramlarının, 1960 ’lı yıllardan sonra ağırlık kazanmaya başladığını belirttiği ve bunun sebeplerine değindiği yazısında şunları söyler:

Eleştiride okurun ön plana çıkmasının nedenleri karmaşıktır (...). Nedenlerden biri, modernist edebîyatın okuru edilgen durumdan çıkararak, karakter, olay, zaman ya da mekân ile ilgili karanlık bırakılmış birçok noktayı çözmeye davet etmesidir. James Joyce, 
Franz Kafka, Allen Robbe-Grillet, W. Faulkner, S. Becket ve daha birçok romancı, şair, oyun yazarı, kimisi az kimisi daha fazla oranda eseri yorumlama ve anlamlama işine okurun da katılmasını gerektiren eserler vermişlerdir. İkinci bir neden daha çok dil ile ilgili. Saussure'den kaynaklanan yapısalcılık, eserdeki anlamı bir cümlenin anlamı gibi, kendi yapısında arıordu. Oysa Derrida bu bilimsel çözümü sorguladı ve metnin nasıl okunacağı konusunda okura ağırlık tanıdı. Ayrıca göstergebilim anlam üreten kodların, konvansiyonların iş göreceği bir yer olarak okura döndü. Bir okur, bir kişi değil, kodların toplandığı anlam kazandığı bir işlevdi. Aynı nedenden ötürü Barthes metnin birliğinin, metnin çıkış noktasında (yazarda) değil, varış noktasında yani okurda oluştuğunu söylüyordu (Moran 1994: 219).

Bir roman, her okurun zihninde farklı algı ve çağrışımlar oluşturabilir. Her okur, okuma sürecinde romandaki belli boşlukları doldurur, çıkarımlar yapar, kendi kültür, duygu ve düşünce dünyasına göre romanı yeniden üretir. Hal böyleyken ve tek bir anlam ve algıdan söz edilemezken, romanın sinemaya uyarlanmasında da bir okur olarak yönetmenin roman algısı ve bu algının aktarımı hesaba katılmalıdır. Metnin anlamlandırılmasında okura birinci dereceden bir rol biçen bu tür yaklaşımların, yönetmenin roman karşısındaki konumuyla ilgili olduğu ve bunun da romanın aktarım sürecindeki işleyişte belirleyici bir rol üstlendiği bilinmelidir.

Romanı içselleştiren yönetmen, eserle birlikte değişir, dönüşür. Roman, yönetmende içkin bir hale gelir ve bir okur olarak kendi hayatı içinde romanı bir estetik deneyim olarak yaşar. Söz konusu estetik tecrübenin dışavurumuysa her okurda olduğu gibi her yönetmende de değişik biçimlerde tezahür edebîlir. Bu itibarla, yönetmenin filmini "yazarken" aslında okuduğu romanı "yorumladığını" düşünmek yanlış olmaz. Böylelikle film, romanın bir okur olarak yönetmen süzgecinden geçmiş bir dışavurumu olur. Sözü edilen dışavurumda, romanın öznel algısının, romanın kendisi ya da bir metin çözümlenmesi olmadığı noktası hatırda tutulmalıdır.

Yazmak nasıl ki "okunanı" bir yorumlama eylemiyse, bir okur olarak yönetmenin okuduğu romanı filme aktarma süreci de bir anlamda yazarın yaptığının aynı, yani bir "okunanın yorumlanması eylemi"dir. "Yorum" sonrasında ortaya çıkacak olan filmdeki sanatsal başarı ya da başarısızlıksa 
tamamen yönetmene aittir. Eco, yazarın bazı durumlarda, "Hayır, ben bunu kastetmedim, ancak metnin bunu söylediğini kabul etmek durumundayım ve okura bana bunu gösterdiği için teşekkür ederim." diyebileceğini söyler (2008: 89). Bu yaklaşım, yönetmene sınırları oldukça geniş bir alanda serbest hareket etme imkânı tanır. Ancak kaynak metni aşan "aşırı yorumlar"ın, romanla film arasındaki bağlantıyı tamamen koparacağı aşikârdır. Bu sebeple kaynak metne "bağlılık", filme aktarım için ön koşuldur.

Todorov'un edebî metin ve eleştirmen arasındaki ilişkiyle ilgili kurduğu cümle, burada roman ve film yönetmeni için de geçerlidir: "Ortada yalnızca okuma değil yazma da bulunduğu için eleştirmen, aynı şeyi söyleme iddiasında olsa bile, incelenen yapıtın söylemediği bir şey söyler. Yeni bir kitap yazdığı için, bahsettiği kitabı ortadan kaldırır" (Todorov 2001: 34).

Bir romanın da birden fazla sinemaya aktarılmış örnekleri olabilir. Sinema tarihi ünlü romanların sinemaya birbirinden farklı yönetmenler tarafindan aktarılmış birçok versiyonuyla doludur. Hatta daha önce okuduğu romanla ilgili, her okuyuşunda farklı algı ve çağrışımlara maruz kalan yönetmen/ okur, teorik olarak aynı romanı sinemaya birçok kez farklı olarak da aktarabilir. Todorov'a göre de bir kitabın iki okuması hiçbir zaman özdeş değildir. Okurken edilgin bir yazma gerçekleştiririz; metinde bulmak istediklerimizi ekler veya bulmak istemediklerimizi çıkarırız (2001: 34). Ancak yönetmenin, romanı yalnızca işlenecek konudan ibaret görmemesi gerekir. Romanı filme aktaracak olan yönetmenin, kaynak eseri yorumlayarak kendi eserine özgünlük katması, ona kendi damgasını vurması, başarı için kaçınılmazdır.

\section{Edebî Romandan Edebî Sinemaya}

\section{Koca bir evreni içinde taşıyan insan: İste benim tek ilgi odăğm. ${ }^{16}$}

Andrei Tarkovski

Yazılı olan her şey edebîyat olmadığı gibi, kameraya alınmış her görüntü de film değildir. Bir romanın ya da bir filmin sanat dairesi içerisinde telakki edilmesini sağlayan bazı nitelikleri olmalıdır. Bir romanın edebîyat sanatı içinde yer alabilmesi için öncelikle yazı ve dil sanatlarına özgü estetik değerleri haiz olması gerekir. Wellek, Edebîyat Teorisi adlı eserinin edebîyatın tabiatı ve işlevi üzerine görüşlerini anlattığı bölümünde (2001: 7-23), edebî şekil ve estetik yönden dikkate değer kitapların, estetik değerle birlikte genel olarak bir fikri üstünlüğe de sahip olduklarını belirtir. Kurgusallık, icat ve 
hayal gücünü, edebîyatın ayırıcı vasfı olarak gören Wellek'e göre, edebîyat eseri, işlevini başarıyla yaptığı zaman zevk ve yarar nitelikleri kaynaşmış olarak onda bulunacaktır. Antik çağda Sokrates, Platon ve Aristo'nun sanat, sanatçı ve estetikle ilgili görüşlerinde de bir şeyin "güzel" olabilmesi için estetik değerle birlikte, doğru, iyi ve faydalı gibi özellikleri de taşıması gerektiği vurgulanır. Horatius' ın "zevkli ve yararlı" (dulce et utile) kavramı da estetik tarihinin esaslarındandır. Geçmişten bugüne sanat konusunda etik ve estetiğin hep bir arada ele alındığı görülür. ${ }^{17}$

Sinemanın da tıpkı edebîyat sanatında olduğu gibi, etik ve kendi varoluş tarzından kaynaklanan görüntü sanatlarına özgü estetik özellikleri bünyesinde barındırması gerekir. Ancak böyle bir filmde sanattan bahsedilebilir. Sanat ve özelde edebîyat için geçerli olan estetik ölçütler sinema sanatı için de geçerlidir.

Sinemanın gerçekliğin mekanik bir kaydı ve dolayısıyla sanat olmadığı yolundaki iddialara karşı çıkan Arnheim, sinema sanatının, resim, müzik, edebîyat ve dansa, sanatsal sonuçlar üretmesi ve fakat bu amaçla kullanılmasının zorunlu olmadığı bir ortam olması bakımından benzediğini belirtir. Arnheim'a göre (2010: 15), renkli resimli kartpostallar sanat değildir ve sanat olmaları amaçlanmaz. Aynı durum bir askeri marş, gerçek itiraflardan oluşan bir öykü ya da striptiz için de geçerlidir. Filmler de mutlaka sanatsal olmak zorunda değildirler.

Ancak edebî bir romandan yola çıkılarak oluşturulmuş bir filmin, romanın konusuyla olan ilgisinden ziyade öncelikle, sanatsal estetik özelliklere sahip olup olmadığına dikkat edilmesi gerekir. Bu itibarla bir filmin romandan alması gereken en önemli unsur "edebîlik"tir. Nasıl ki bir romanın edebî oluşu, onun etik ve estetiği bir arada taşımasını ve bu kavramların romanın her unsurunda bulunuyor olmasını ifade ediyorsa; edebî bir romanın filme aktarım süreci sonunda ortaya çıkacak ürünün de sinema estetiği çerçevesinde bir edebîliği taşıyor olması beklenir.

Romanın yönetmen tarafından yalnızca bir konu kaynağı olarak görülmesi, romanı değil yönetmeni bağlamalıdır. Yalnızca konuya indirgenmiş bir edebî romanın, herhangi bir üçüncü sayfa haberinden farkı yoktur. Oysa bir romanı edebî yapan şey konusundan ziyade konuyu işleyiş biçimi ve sahip olduğu edebî dildir. Wellek edebî dili şöyle tavsif eder: 
O, ileri derecede 'dolaylı anlamlı veya çağrışımlı (connotative)' bir dildir. Bundan başka o, sadece bizi anlatacağı şeye götüren (referential) bir dil değildir. Edebî dilin tesirli, kendine has bir ifade özelliği vardır. Konuşan veya yazan kişinin havasını ve tutumunu taşır. Gene bu dil söyleyeceğini sadece öylemek veya ifade etmekle yetinmez, okuru etkilemek, ikna etmek ve nihayet değiştirmek ister (Wellek vd. 2001: 10).

Romanın, yönetmen tarafindan sadece faydalanılacak bir konu veya yalnızca bir "malzeme" olarak görülmesi kimi yazarları rahatsız eder. Bu böyle olsa bile, güçlü bir roman, filme yapılan her çeşit uyarlama neticesinde hala ayakta kalabilen romandır. Dostoyevski, Tolstoy ya da Shakespare gibi yazarların eserleri çoğu kez sinemaya aktarıldı̆̆ı ancak, yapılan filmlerin hiçbirinin, söz konusu yazarların eserlerini gölgede bırakamadığı aşikârdır.

"Sinemaya en fazla uyarlanan Dostoyevski romanlarından biri 'Suç ve Ceza'dır. Ekspresyonist sinemanın büyük ustası ve 'Doktor Caligari'nin yönetmeni Robert Wiene’nin 1923 yapımı 'Raskolnikow'u 'Suç ve Ceza'nın ilk uyarlamalarından birisi olarak dikkat çeker. Özellikle set tasarımı açısından çarpıcı olan film, yine de büyük bir başarısızlık olarak akıllarda kalır" (Gülşen 2011: 170).

Edebî sinema, sinemayı bir sanat olarak görenler ve onların ürettiklerince somut hale gelebilecek bir kavramdır. Söz konusu sinema biçiminin örnekleri sinema tarihinde azımsanmayacak sayıda mevcuttur. Eisenstein, Tarkovski, Kurosawa, Bergman, Antonioni, Angelopulos, Truffaut, Kiyarüstemi gibi birçok yönetmen bu türden bir sinemanın temsilcisi sayılabilirler. Mezkûr yönetmenlerin sinema anlayışları farklı bile olsa, sanat ve sinema estetiği üzerine düşünce üretmiş, yalnızca gişeyi düşünmeyerek yaptıkları işin fikri acısını çekmiş ve bu tarzda filmler üretmiş olmaları bakımından onları edebî sinema kavramı içerinde düşünmek yanlış olmaz.

\section{Sonuç}

Sinemada insan ne söyleyeceğini çok iyi bilirse, çekeceği filmin her satırın kafasında canlandirabiliyor, açıkça algılayabiliyorsa teknik açıdan çözülemeyecek hiçbir ifade sorunu yoktur. ${ }^{18}$ 
İnsanoğlunun gördüklerini kopyalayıp gerçek hayatta olduğu gibi onlara devinim katma rüyası, 19. yüzyılın sonlarına doğru sinematografın icadıyla birlikte gerçeğe dönmüştür. İlk filmlerden bugüne kadar sinema sanatı ile edebîyat sürekli etkileşim halinde olmuş ve birçok edebîyat eseri, özellikle de romanlar, filme aktarılmıştır.

Romanların filme aktarımı, her iki sanatın doğasına özgü varoluş tarzları ve birbirinden farklı anlatım dillerinden kaynaklanan sorunları da beraberinde getirmiştir. Bize göre bu sorunların kaynağının başında görüntünün doğasına ait bir kavram olan, "gerçeklik yanılsaması" gelmektedir. Gerçekliğin devinimli bir biçimde kopyalanabilmesi, insanın gerçek ile gerçeğin kopyası olan görüntüyü birbirinden ayıramamalarına sebep olmuş, bu da romanlardaki soyut kavram ve durumların görüntü diline aktarılmasını güçleştirmiştir. Oysa görüntü, gerçeğin kendisi değil, bir göstergesidir. Görüntülerden oluşan film de dolayısıyla doğrudan doğruya somut gerçekliğe değil bu gerçekliğin arkasındaki anlamlara işaret etmelidir. Bir romanın sinemaya aktarımındaki problemler aslında romanla sinema arasındaki ilişki biçiminden değil, görüntü ve gerçeklik arasındaki ilişki biçiminin doğru kurulamamasından kaynaklanır. Görüntüye böyle bir bilinçle yaklaşmak, soyut kavram ve durumların aktarılmasındaki problemlerin aşılmasında kolaylık sağlayacaktır.

Günümüz dünya sineması, gerçekliği olduğu gibi görerek onun tam bir kopyasını yansıtmaya çalışan ve bunun neticesinde de üç boyut ya da daha farklı teknolojileri de kullanarak gerçeklik yanılsamasını giderek arttıran bir anlayış ile bu anlayıştan farklı olarak, gerçekliğin kendisinin aslında bir yanılsama olduğunun bilinciyle sinema estetiğinin içinde görüntünün arkasındaki farklı anlam katmanlarını iletmeye çalışan anlayış olmak üzere, iki ayrı yoldan ilerlemektedir. ${ }^{19}$ Bize göre bunların ilki sinemanın zanaat yanının, ikincisi ise sanat yanının sergilenmesine imkân tanır. Edebî bir romanı kaynak alan filmlerinse, sinemanın sanatsal olan yanında durmasını beklemek, gayet tabiidir.

Romanı, filme kaynaklık eden bir hareket noktası olarak görmek, yahut yönetmeni sayısız roman okurundan herhangi biri olarak telakki etmek, yönetmenin film üzerinde estetik değerlerden uzaklaşarak istediği gibi tasarruf edeceği anlamına gelmez. Aksine, romana ister uzak ister yakın bir mesafede olsun, edebî bir romandan yola çıkarak bir film yapan yönetmenin, filmine 
katması gereken en önemli değer romanın edebî ve estetik yönü olmalıdır. Türk sinemasının hala bir poetikadan yoksun olduğu göz önünde bulundurulursa edebî sinema kavramına ve sinemada edebîliğe yapılan vurgular daha anlamlı olacaktır.

\section{Açılamalar}

1 Sinemanın ve "sinematograf"ın tarihine dair geniş bilgi için bkz: Alim Şerif Onaran (1994). Sessiz Sinema Tarihi. Ankara: Kitle Yay.; Paul Rotha (2000). Sinemanın Öyküsü. İstanbul: İzdüşüm Yay.; Mustafa Gökmen (1989). Başlangzçtan 1950'ye Kadar Türk Sinema Tarihi ve Eski İstanbul Sinemalar. İstanbul: Denetim Ajans Basımevi; Rekin Teksoy (2005). Rekin Teksoy'un Sinema Tarihi. İstanbul: Oğlak Yay.

2 Eisenstein, Japon kavramsal yazısına çoğunlukla hiyeroglif der. (Film Biçimi kitabını çevirenin notu).

3 "Kurgu" ile ilgili daha ayrıntılı bilgi için bk: A.G. Sokolov (2007). Sinema ve Televizyonda Görüntü Kurgusu. Çev. S. Aslanyürek. İstanbul: Agora Kitapl1ğ1; M. Toprak (2012). Film Dili, Kurgu. İstanbul: Kalkedon Yay.

4 Rus sinema kuramcısı Lev Kuleşov, kurguyla ilgili yaptığı deneyde üç farklı görüntüden yalnızca birini değiştirmek suretiyle üç farklı film ortaya çıkarır. Birincisi, "oyuncunun yüzü+çorba dolu bir tabak+oyuncunun yüzü"; ikincisi, "oyuncunun yüzü+tabutta yatan kadın+oyuncunun yüzü"; üçüncüsü, "oyuncunun yüzü+küçük bir kız çocuğu+oyuncunun yüzü" şeklindedir. Yapılan deneyde bu üç görüntü dizgesi seyircilere gösterilmiş ve duyguları sorulmuştur. Sonuçta da birinci filmdeki duygunun "açlık"; ikinci filmdekinin "üzüntü" ve üçüncü filmdeki duygunun ise "sevgi" olduğu tespit edilmiştir. Buna sinemada "Kuleşov Etkisi" adı verilir.

5 Orjinal adı "Khane-ye doust kodjast?" olan "Arkadaşımın Evi Nerede?", 1987 İran yapımı Abbas Kiyarüstemi filmidir. Yönetmenin Köker Üçlemesinin ilk filmi kabul edilir.

6 Orjinal adı "Hamsarayan" olan "Koro", 1982 İran yapımı Abbas Kiyarüstemi filmidir. Yönetmenin kısa filmlerinden biridir.

7 E. Batur (1995). Yazının Ucu. İstanbul: YKY. 296.

8 Bu çalışmanın sınırları gereği olarak makalede, romandan filme yapılan uyarlamalar üzerinde durulmuştur.

9 Elbette sinema kollektif bir üretim ve sanattır. Fakat üretim sürecini başından sonuna kadar yöneten, kararlar alan, tercihlerde bulunan ve filme imzasını koyan kişi olarak filmin, yönetmenin eseri olduğu söylenebilir.

10 Fransız yönetmen Claude Autant'ın, orjinal adı "Le Diable Au Corps" olan 1947 yapımı filmi.

11 Fransız yönetmen Jean Delannoy’un, orjinal adı "La Symphonie Pastorale" olan 1946 yapımı filmi. 
12 Guy De Mauppassant'ın bir öyküsünden uyarlanan "Bir Kır Eğlencesi" adlı filmin yapım tarihi 1936'dır.

13 Gustave Flaubert'in 1857 tarihli aynı adlı romanından uyarlanmış 1934 yapimı film.

14 Robert Bresson'un yönetmenliğini yaptığı film 1951 yapımıdır ve Georges Bernanos'un Bir Taşra Papazının Günlüğü adlı romanından uyarlanmıştır.

15 Andrei Tarkovsky'nin "Stalker" (İz Sürücü) adlı 1979 yapımı filmi, Boris ve Arkady Strugatsky kardeşlerin Yol Kenarında Piknik adlı romanının bir uyarlamasidir.

16 A. Tarkovski (2008). Mühürlenmiş Zaman. Çev. F. Ant. İstanbul: Agora Kitaplığı. 181.

17 Konuyla ilgili bk. İ. Tunalı (2004). Estetik. İstanbul: Remzi Kitabevi; R. Wellek and A. Varren (2001). Edebîyat Teorisi. Çev. Ö.F. Huyugüzel. İzmir: Akademi Kitabevi; B. Moran (1994). Edebîyat Kuramları ve Eleştiri. İstanbul: Cem Yay.

18 A. Tarkovski (2008). Mühürlenmiş Zaman. Çev. F. Ant. İstanbul: Agora Kitaplığı. 97.

19 Bu itibarla, Hollywood ve İran sinemaları iki karşıt kanalın birer temsilcisi gibidirler.

\section{Kaynaklar}

Arnheim, Rudolf (2010). Sanat Olarak Sinema. Çev. R.Ü. Tamdoğan. İstanbul: Hil Yay.

Barthes, Roland (2014). Camera Lucida Fotoğraf Üzerine Düşünceler. Çev. R. Akçakaya. İstanbul: Altıkırkbeş Yay.

Batur, Enis (1995). Yazının Ucu. İstanbul: YKY.

Bazin, Andre (2011). Sinema Nedir?. Çev. İ. Şener. İstanbul: Doruk Yay.

Eco, Umberto (2008). Yorum ve Aşırı Yorum. Çev. K. Atakay. İstanbul: Can Yay.

Eisenstein, Sergey M. (1985). Film Biçimi. Çev. N. Özön. İstanbul: Payel Yay.

Gombrich, Ernst H. (1997). Sanatın Öyküsü. Çev. E. Erduran ve Ö. Erduran. İstanbul: Remzi Kitabevi.

Gülşen, Enver (2011). Sinemanın Hakikati. İstanbul: Külliyat Yay.

Leaman, Oliver (2012). İslam Estetiğine Giriş. Çev. N. Yılmaz. İstanbul: Küre Yay.

Lotman, Yuriy M. (1999). Sinema Estetiğinin Sorunları. Çev. O. Özügül. Ankara: Öteki Yay.

Moran, Berna (1994). Edebîyat Kuramları ve Eleştiri. İstanbul: Cem Yay.

Tarkovski, Andrei (2009). Şiirsel Sinema. Çev. E. Kılıç. İstanbul: Agora Kitaplığı.

Todorov, Tzvetan (2001). Poetikaya Giriş. Çev. K. Şahin. İstanbul: Metis Yay.

Wellek, Rene ve Austin Varren (2001). Edebîyat Teorisi. Çev. Ö.F. Huyugüzel. İzmir: Akademi Kitabevi. 


\title{
The Theoretical Approaches to The Problems Encountered while from A Novel into A Film*
}

\section{Orhan Güdek ${ }^{* *}$}

\begin{abstract}
The aim of this study is to investigate the relationships between written and visual narratives and to bring solutions to specific problems emerging in the process of transferring a novel into a film. 'Illusion of reality" may be seen as the main source of these problems. In this study it is suggested that these problems stem from not because the from of relationshisps between a novel and a film, but because of the lack of the attributing the idealized meaning between image and reality. The way of thinking that image conveys the sememic stratums behind the reality and is the sign of reality makes it much easier for the director to transfer the abstract notions and states from a novel. The study also handles the problems of fidelity and inquires the distance of the director to the novel theoritically. Films using the literary novels as base should be located on the artistic side of the cinema and the most crucial quality to be adapted from a novel is "literariness".
\end{abstract}

\section{Keywords}

Novel, movie, written narrative, visual narrative, adaptation, illusion of reality, theory.

"Date of Arrival: 15 January 2016 - Date of Acceptance: 21 December 2016

You can refer to this article as follows:

Güdek, Orhan (2019). "Romanın Sinemaya Aktarımında Karşılaşılan Problemlere Kuramsal Yaklaşımlar". bilig - Journal of Social Sciences of the Turkic World 90: 117-135.

** PhD, Sakarya University, Institute of Social Sciences, Department of Turkish Language and Literature - Sakarya/Turkey

ORCID ID: https://orcid.org/0000-0001-9928-1612

orhangultenzey@gmail.com 


\title{
Теоретические подходы к адаптации романа в фильм*
}

\section{Орхан Гюдек}

\begin{abstract}
Аннотация
Цель этой работы - изучить связи между письменными и визуальными источниками и предложить решения для некоторых проблем, возникающих при кинематографической адаптации романа. В данной работе основной причиной этих проблем считается нечто присущее визуальным медиа, а именно иллюзия реальности. Проблемы при адаптации возникают не из-за отношения между романом и фильмом, а из-за несоответствия между реальностью и изображением. То, что изображение является отражением реальности, а также отражает слои помимо реальности, дает режиссерам массу возможностей. Также было проведено теоретическое исследование близости адаптации к первоисточнику. Считается, что фильмы, основанные на литературных романах, должны придерживаться художественности и литературности.
\end{abstract}

\section{Ключевые слова}

Роман, кинематограф, письменные медиа, визуальные медиа, адаптация, иллюзия реальности, теория.

\footnotetext{
* Поступило в редакцию: 15 января 2016 г. - Принято в номер: 21 декабря 2016 г. Ссылка на статью:

Güdek, Orhan. (2019). "Romanın Sinemaya Aktarımında Karşı1laşılan Problemlere Kuramsal Yaklaşımlar". bilig - Журнал Гуманитарных Наук Тюркского Мира 90: 117-135.

** Д-р, Университет Сакарьи, институт социальных наук, кафедра турецкого языка и литературы, отделение турецкого языка и литературы - Сакарья/Турция ORCID ID: https://orcid.org/0000-0001-9928-1612 orhangultenzey@gmail.com
} 